\title{
A new species of the genus Proxichione (Bivalvia: Veneridae) from Western Australia with notes on Late Tertiary species
}

\author{
Thomas A. Darragh \\ Department of Invertebrate Palaeontology, Museum Victoria, G.P.O. Box 666, Melbourne Victoria 3001, Australia. \\ E-mail: tdarragh@museum.vic.gov.au
}

\begin{abstract}
Proxichione elimatula sp. nov. is described from the west and south coasts of Western Australia. Proxichione moondarae Darragh, 1965 is recorded from the Late Miocene of South Australia and Late Pliocene of Flinders Island, Tasmania. Proxichione cognata (Pritchard, 1903) is recorded from the Roe Calcarenite (Late Pliocene) of Western Australia.
\end{abstract}

Keywords: new taxon, Murray Basin, Bass Basin.

\section{INTRODUCTION}

Australian fossil species of Proxichione were revised and the genus differentiated from similar looking taxa of the Veneridae by Darragh (1965). Since that time specimens of a new living congeneric species have been accumulating in the collections of the Western Australian Museum. In addition, the geographical and stratigraphical range of the genus has been extended. Fossils of Proxichione moondarae Darragh, 1965 have been collected in South Australia and on Flinders Island, Tasmania. Maxwell (1978) extended the range of the genus to New Zealand by describing two taxa from the Duntroonian and Waitakian (Oligocene) of the South Island. Ludbrook (1978) extended the range of fossils of the genus to Western Australia by recording the occurrence of Proxichione sp. cf. P. cognata (Pritchard 1903) in the Roe Calcarenite (Late Pliocene, Eucla Basin). The stratigraphical range of the genus is now recognised as extending from the Late Oligocene to Recent in Australia, and in the Late Oligocene in New Zealand.

Species of Proxichione are the largest of the Australian fossil and living venerids and are amongst the largest of all Australian infaunal bivalves. There are four living species of the genus ranging from the Great Australian Bight westwards and northwards around the coast of Western Australia to the Northern Territory, Queensland and New South Wales to about Eden, in depths from just below low tide level to about 200 metres. The species are P. materna Iredale, 1929 (distributed from central to southern New South Wales), P. chemnitzii (Hanley, 1845) (distributed from north-western Western Australia to northern New South Wales and extending into the western Indo-Pacific as far as India and Madagascar), $P$. elimatula sp. nov. (distributed from the Great
Australian Bight westwards and northwards to off Kalbarri, Western Australia) and the smallest of the species P. persimilis (Iredale, 1930) (distributed from central New South Wales northwards to southern Queensland). This last species was designated as the type species of Tigammona Iredale, 1930 (Figure 1G-L).

Proxichione belongs to a group of venerid bivalves with prominent comarginal and radial sculpture. The radial sculpture consists of simple, rounded ribs, whereas the comarginal sculpture consists of prominent erect lamellae, which are corrugated where they cross the ribs and may be recurved towards the umbones of the shell. The oldest named genus of this group is Antigona, which has been used by some authors (e.g. Lamprell and Whitehead 1992; Jansen 2000) to include species now placed in Proxichione. The differential characters that distinguish these similar looking taxa are summarised as below.

\section{Antigona Schumacher, 1817 \\ (Figure 1A-F)}

Type species: A. lamellaris Schumacher, 1817

\section{Diagnosis}

Shell small; pallial sinus small and triangular; left anterior lateral tooth well developed and the corresponding socket in the right valve well defined; escutcheon wide and well defined on both valves.

\section{Proxichione Iredale, 1929 \\ (Figure 2G-I, K-L)}

Type species: P. materna Iredale, 1929 

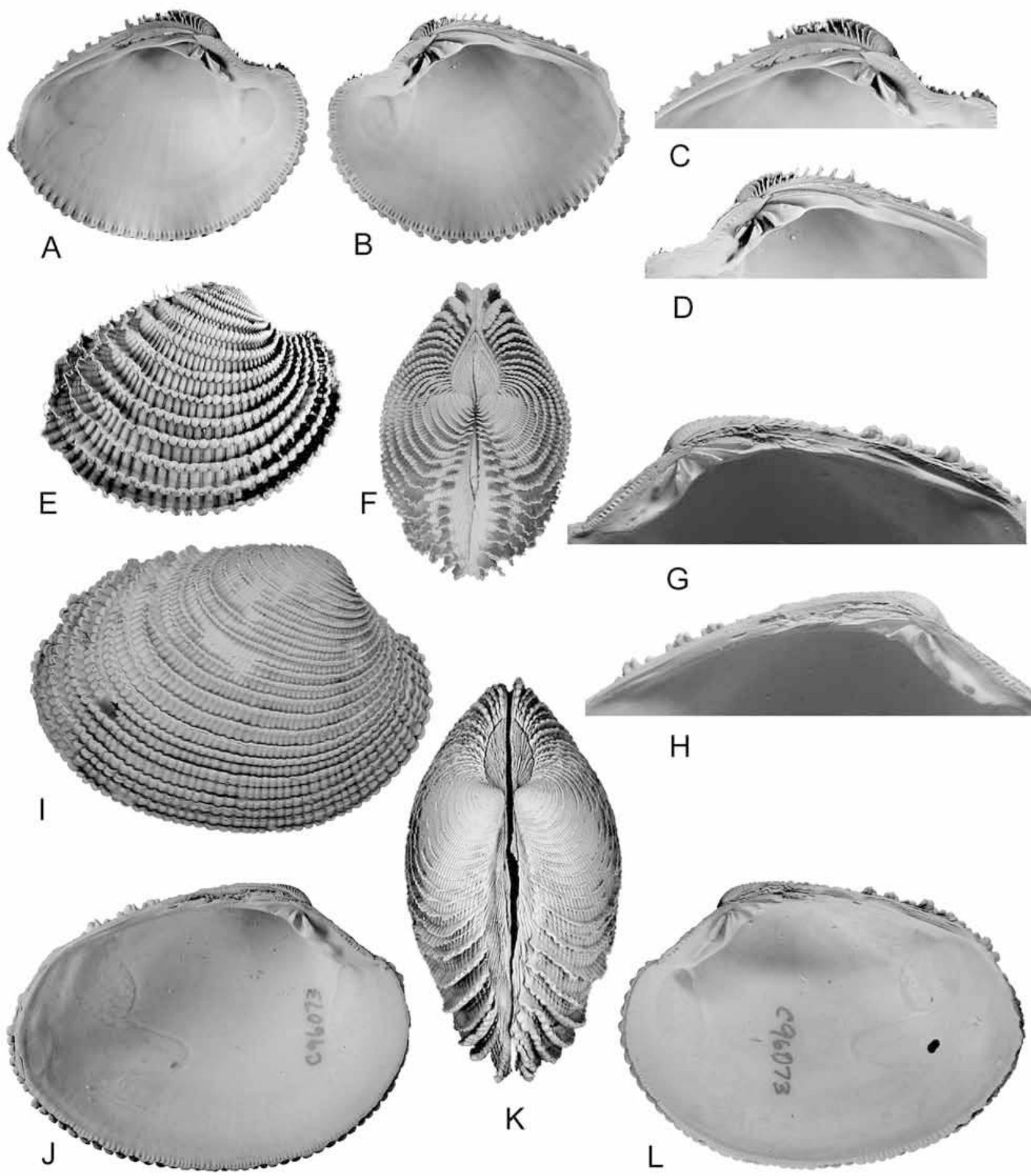

Figure 1 A-F: Antigona lamellaris Schumacher, 1817, Lacepede Islands, Western Australia, conjoined valves (NMV F 157434) (A-B, E- F x 1.5, C, D x 2); G-L: Proxichione persimilis (Iredale, 1929), Whale Point, Crookhaven Bight, New South Wales, conjoined valves (AM C 96073) (G-H x 2, I, J-L x 1.5).

\section{Diagnosis}

Shell generally large; pallial sinus large and angular; left anterior lateral tooth weakly developed; escutcheon on right valve very weakly developed.

The genus Antigona has no fossil record in Australia. Its living species inhabit very shallow water in northern New South Wales, Queensland,
Northern Territory, and northern Western Australia.

Of the other genera mentioned by Darragh (1965), Periglypta Jukes-Browne, 1914 (Figure 2A-C) is easily distinguished by the presence of a large rounded pallial sinus and a prominently grooved escutcheon. The genus Ameghinomya von Ihering, 1907 (Type species: Venus volckmanni var. argentina, von Ihering, 1897) resembles Periglypta. It was 

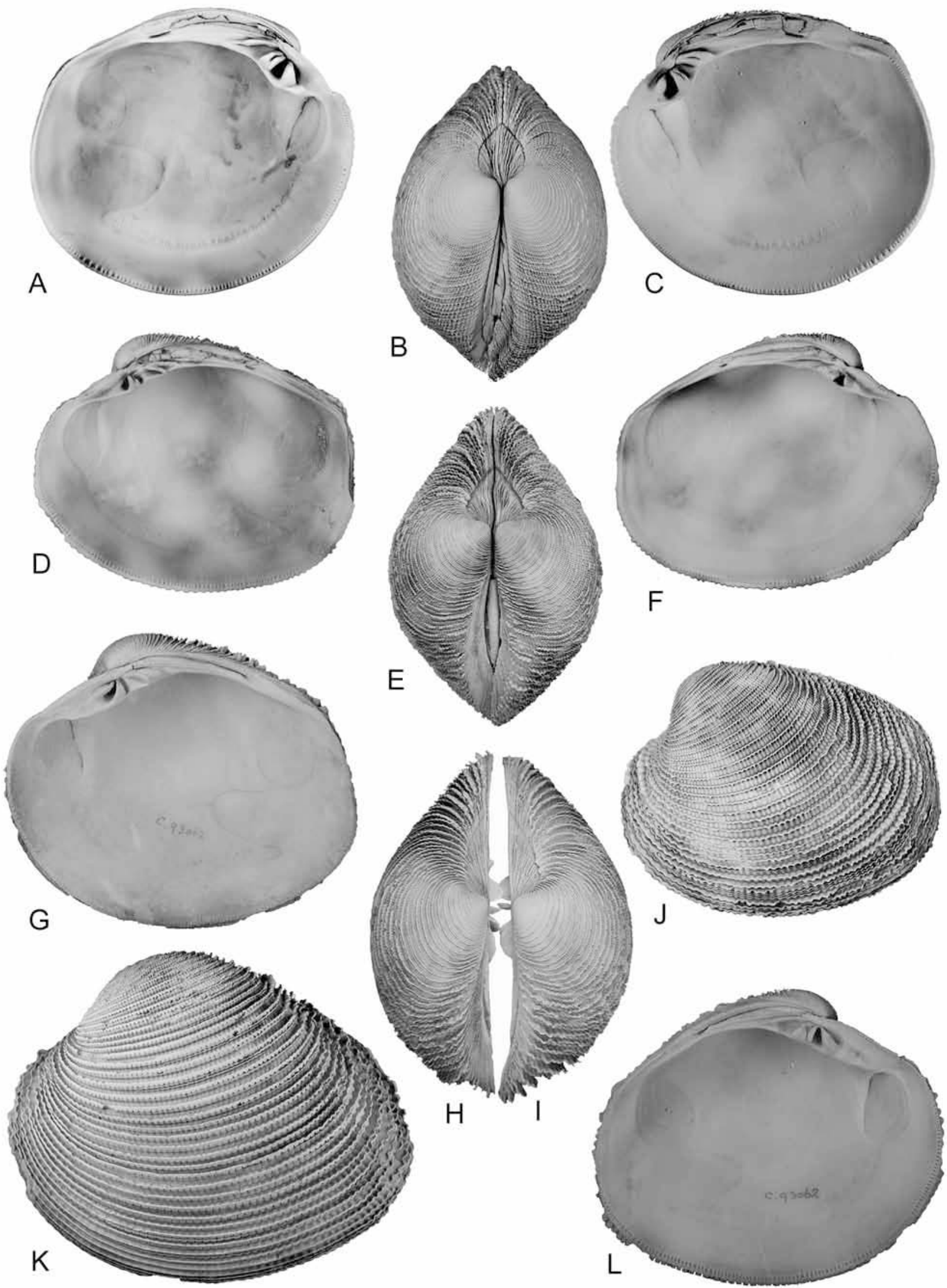

Figure 2 A-C: Periglypta puerpera (Linnaeus, 1771), Rudder Reef, Port Douglas, Queensland, conjoined pair (NMV F157432) (A-C x 1); D-F, J: Proxichione chemnitzii (Hanley, 1845), Safety Bay, Western Australia, conjoined valves (NMV F157435) (D-F, J x 0.75). G-I, K, L: Proxichione materna Iredale, 1929, Sydney Harbour, New South Wales, G, I, AM C93062c; H, L, AM C92062b; K, AM C93062a (all x 0.75). 
little known in 1965 but a description and figures of the type species given by Del Rio (1994) show there are considerable morphological differences when it is compared to Periglypta, having a smooth escutcheon, a small and triangular pallial sinus and a lack of commarginal recurved lamellae on the outer surface of the valves.

Maxwell (1978) stated that Proxichione resembles the venerid genus Dosina Gray, 1835 (type species D. zelandica Gray, 1835) but pointed out several distinguishing features. The most important of these is that species of Proxichione have prominent radial sculpture, whereas species of Dosina have very poorly developed radial sculpture or none at all.

\section{TERMINOLOGY AND ABBREVIATIONS}

Shell length is the maximum dimension of a valve measured parallel to a line between the midpoints of the two muscle scars. Shell height is the maximum dimension of a valve measured at right angles to the shell length. The inflation is the maximum thickness of one valve.

The specimens studied are lodged in the following institutions: Australian Museum, Sydney (AM); Museum Victoria, Melbourne (NMV); Western Australian Museum, Perth (WAM). Fossil locality numbers, prefixed PL, are listed in the Museum Victoria fossil locality register.

\section{SYSTEMATICS}

\section{Class Bivalvia Linné, 1758}

\section{Family Veneridae Rafinesque, 1815}

\section{Genus Proxichione Iredale, 1929}

Proxichione Iredale, 1929: 339; Darragh, 1965: 166; Maxwell, 1978: 25.

Tigammona Iredale, 1930: 396.

\section{Type species}

Proxichione: Proxichione materna Iredale, 1929, by original designation, from Sydney Harbour, New South Wales.

Tigammona: Tigammona persimilis Iredale, 1930, by original designation, from Manly, New South Wales.

\section{Proxichione elimatula sp. nov.}

Figures 3A-I

\section{Material examined}

Holotype

Australia: Western Australia: 1 left valve, NW. of
Green Island, $30^{\circ} 34^{\prime} \mathrm{S}, 114^{\circ} 44^{\prime} \mathrm{E}$, HMAS Diamantina Station DM1/72/068-3, B.R. Wilson, 22 March 1972, 128 metres (WAM S34274)

\section{Paratypes}

Australia: Western Australia: 1 right valve, WNW of Cape Vlaming, Rottnest Island, FV "Bluefin" Stn. 29; 61-70 fathoms, dredged, 15 August 1962, B.R. Wilson (WAM S41325); conjoined valves, W of west end Rottnest Island, FV 'Bluefin', 16 Sept. 1965, 90 fathoms (WAM S41328); 1 right valve, W of Rottnest Island, $32^{\circ} 00^{\prime} \mathrm{S}, 115^{\circ} 16^{\prime} \mathrm{E}$, HMAS Diamantina Station DM6/63/225, 12 October 1963, 75-78 fathoms (WAM S34451); 1 left valve, SW of Dongara, $29^{\circ} 49^{\prime} \mathrm{S}, 112^{\circ} 24^{\prime} \mathrm{E}$, HMAS Diamantina Station DM6/63/214, 11 October 1963 70-72 fathoms (WAM S34452).

\section{Other material}

Australia: Western Australia: NW of Bunbury, $32^{\circ} 57.5^{\prime} \mathrm{S}, 114^{\circ} 48^{\prime} \mathrm{E}$, HMAS Diamantina Station DM1/72/008, B.R. Wilson, 15 March 1972, 122-139 metres, 1 right valve (WAM S34260); SW of Mandurah, $32^{\circ} 41^{\prime} \mathrm{S}, 114^{\circ} 51^{\prime} \mathrm{E}$, HMAS Diamantina Station DM1/72/030, B.R. Wilson, 17 March 1972, 146-150 metres, 2 fragments (WAM S34261); W of Garden Island, $32^{\circ} 15.7^{\prime} \mathrm{S}, 115^{\circ} 06.7^{\prime} \mathrm{E}$, HMAS Diamantina Station DM1/72/033, B.R. Wilson, 18 March 1972, 176-182 metres, 2 right valves (WAM S34262); W of Garden Island, 32 ${ }^{\circ} 19^{\prime} \mathrm{S}, 11507^{\prime} \mathrm{E}$, HMAS Diamantina Station DM1/72/034, B.R. Wilson, 18 March 1972, 148-154 meters, 6 left valves and 5 right valves (WAM S34263); W of Rottnest Island, $32^{\circ} 00^{\prime} \mathrm{S}, 115^{\circ} 15^{\prime} \mathrm{E}$, HMAS Diamantina Station DM1/72/78.2, B.R. Wilson \& L. Joll, 23 March 1972, 146-150 metres, 1 left valve and 2 right valves (WAM S34264); W of west end of Rottnest Island, FV 'Bluefin' Stn 1, B.R. Wilson, 10 August 1962, 80 fathoms, 2 fragments (WAM S41337); NW of Rottnest Island, FV 'Bluefin' Station 31, B.R. Wilson, 15 August 1962, 85 fathoms, 1 right valve (WAM S41336); W of Rottnest Island, $32^{\circ} 00^{\prime} \mathrm{S}, 115^{\circ} 15^{\prime} \mathrm{E}$, HMAS Diamantina Station DM1/72/078, B.R. Wilson \& L. Joll, 23 March 1972, 146-150 metres, 1 left valves and 2 fragments (WAM S34267); W of Rottnest Island, $32^{\circ} 00^{\prime} \mathrm{S}, 115^{\circ} 15^{\prime} \mathrm{E}$, HMAS Diamantina Station DM1/72/078, B.R. Wilson \& L. Joll, 23 March 1972, 146-150 metres, 1 left valve and 1 right valve (WAM S34768); W of Rottnest Island, $32^{\circ} 01^{\prime} \mathrm{S}, 115^{\circ} 14^{\prime} \mathrm{E}$, HMAS Diamantina Station DM1/70/057, 28 November 1970, 100 fathoms, 1 right valve (WAM S34269); W of Rottnest Island, $32^{\circ} 00^{\prime} \mathrm{S}, 115^{\circ} 15^{\prime} \mathrm{E}$, HMAS Diamantina Station DM1/72/078, B.R. Wilson.\& L. Joll, 23 March 1972, 146-150 metres, 3 fragments (WAM S34270); W of Rottnest Island, $32^{\circ} 00^{\prime} \mathrm{S}, 115^{\circ} 16^{\prime} \mathrm{E}$, HMAS Diamantina Station DM6/63/225, 12 October 1963, 75-78 fathoms, 2 left valves and 3 right valves (part 

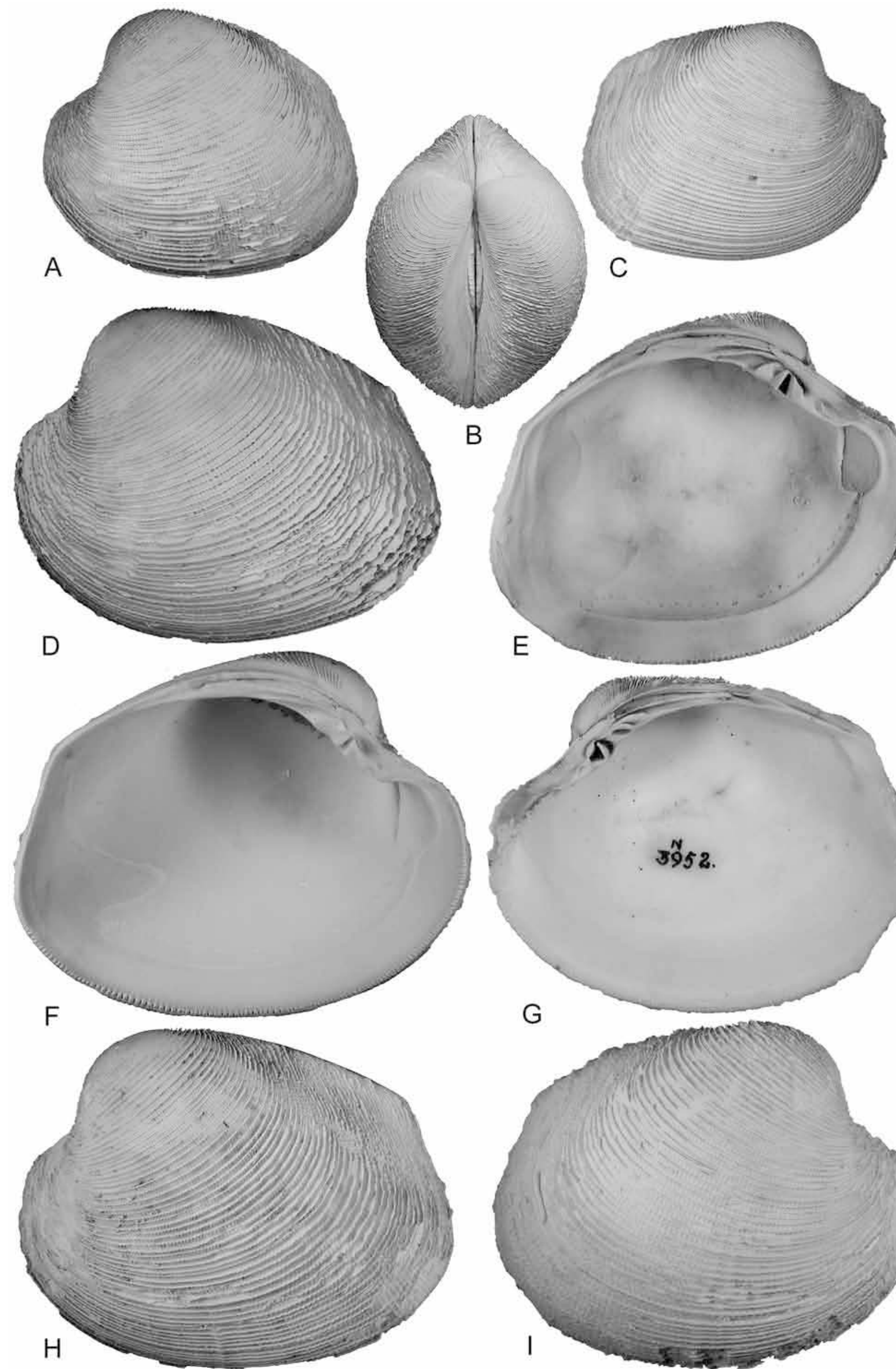

C
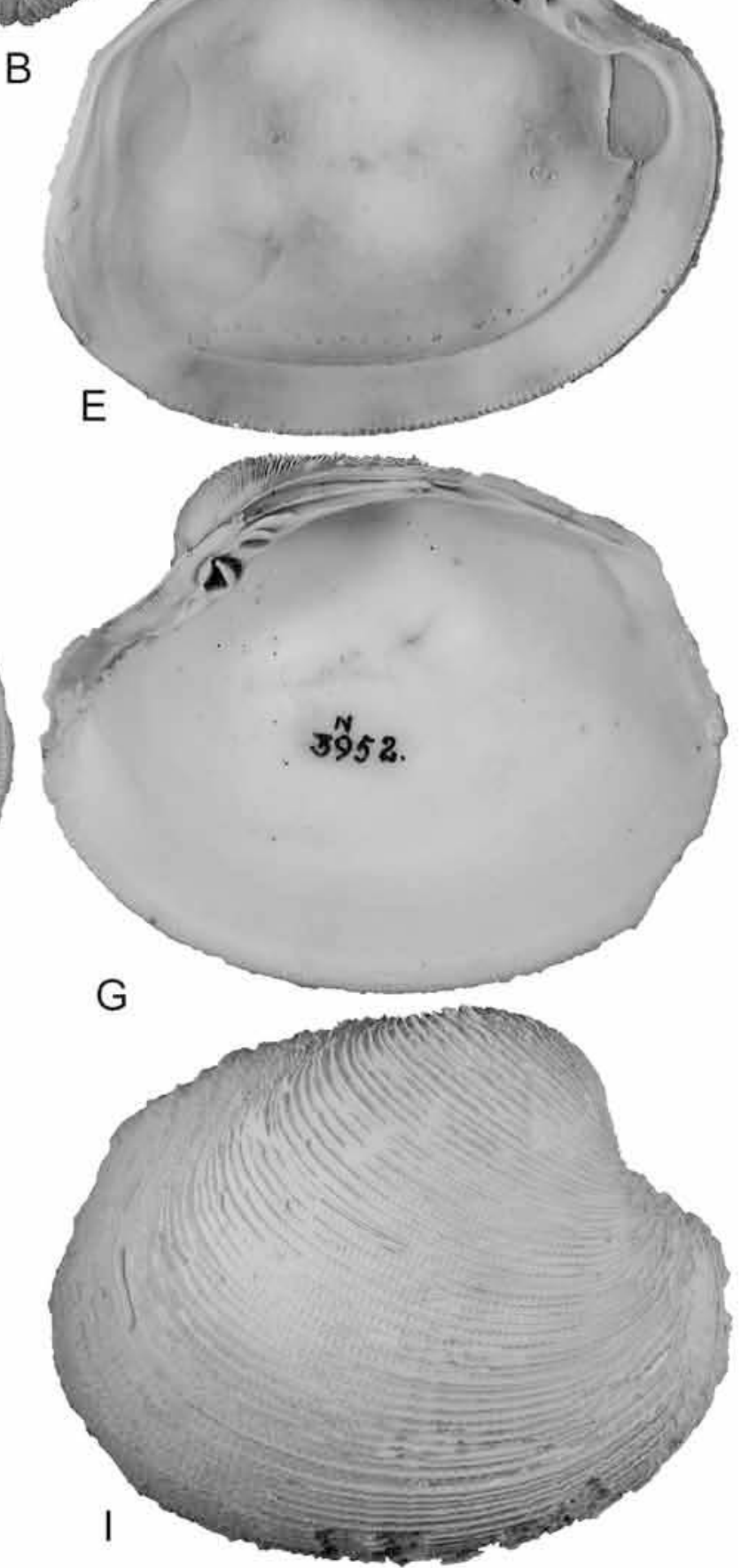

Figure 3 Proxichione elimatula, sp. nov:: A-B: W of west end of Rottnest Island, Western Australia, conjoined pair (WAM S41328), paratype; C, W of Rottnest Island, Western Australia (WAM S34451), paratype; D-E, SW of Dongara, Western Australia (WAM S34452), paratype; F, H, NW of Green Island, Western Australia (WAM S34274), holotype; G, I, NNW of Cape Vlaming, Western Australia(WAM S41325), paratype (all x 1). 
of S41326); W of Rottnest Island, $32^{\circ} 00^{\prime} \mathrm{S}, 115^{\circ} 08^{\prime} \mathrm{E}$, HMAS Diamantina Station DM6/63/144, 28 August 1963, 75 fathoms, 1 left valve (WAM S41327); WNW of Rottnest Island, FV 'Bluefin' Stn 21, B.R. Wilson, 14 August 1962, 80-90 fathoms, 1 left valve (WAM S41335); NNW of Rottnest Island, FV 'Bluefin' Stn 28, B.R. Wilson, 15 August 1962, 65-70 fathoms, 1 left valve (WAM S41334); W of Lancelin Island, $31^{\circ} 05^{\prime} \mathrm{S}, 114^{\circ} 55^{\prime} \mathrm{E}$, CSIRO Station 46, 5 February 1964, 62-67 fathoms, 1 left and 2 right valves (WAM S41333); W of Guilderton, $31^{\circ} 34^{\prime} \mathrm{S}, 115^{\circ} 06^{\prime} \mathrm{E}$, HMAS Diamantina Station DM1/72/077, B.R. Wilson, 23 March 1972, 106-110 metres, 2 left valves (WAM S34271); W of Guilderton, $31^{\circ} 30^{\prime} \mathrm{S}, 114^{\circ} 56^{\prime} \mathrm{E}$ to $31^{\circ} 34^{\prime} \mathrm{S}$, $115^{\circ} 06^{\prime} \mathrm{E}$, HMAS Diamantina Station DM1/72/076, B.R. Wilson, 146 metres, 4 left valves (WAM S34272); W of Guilderton, $31^{\circ} 45^{\prime} \mathrm{S}, 115^{\circ} 06^{\prime} \mathrm{E}$, HMAS Diamantina Station DM1/72/077, B.R. Wilson, 23 March 1972, 106-110 metres, 1 right valve (WAM S34273); NW of Rottnest Island, $31^{\circ} 45^{\prime} \mathrm{S}, 115^{\circ} 09 \mathrm{E}^{\prime}$, HMAS Diamantina Station DM1/72/038, B.R. Wilson, 18 March 1972, 144-150 metres, 1 right valve (WAM S34265); NW of Green Island, 30 37'S, $114^{\circ} 44^{\prime} \mathrm{E}$, HMAS Diamantina Station DM1/72/068-1, B.R. Wilson, 22 March 1972, 139-146 metres, 1 right valve and 2 fragments (WAM S34275); W of Cervantes, $30^{\circ} 33^{\prime} \mathrm{S}, 114^{\circ} 32^{\prime} \mathrm{E}$, HMAS Diamantina Station DM1/72/043, B.R. Wilson, 19 March 1972, 154 metres, 1 left valve (WAM S34276); SW of Jurien Bay, $30^{\circ} 38^{\prime} \mathrm{S}, 114^{\circ} 47^{\prime} \mathrm{E}$, HMAS Diamantina Station DM1/70/108, 9 December 1970, 60 fathoms, 2 left valves and two right valves (WAM S34277); $40 \mathrm{~km}$ $\mathrm{W}$ of Jurien Bay, $30^{\circ} 15.9^{\prime} \mathrm{S}, 114^{\circ} 38.6^{\prime} \mathrm{E}$ to $30^{\circ} 16.5^{\prime} \mathrm{S}$, $114^{\circ} 38.7^{\prime} \mathrm{E}, \mathrm{RV}$ Sprightly Station 40M, S.M. SlackSmith, 20 February 1978, 137.2 metres, 2 left valves and 3 right valves (WAM S34278); SW of Dongara, $29^{\circ} 49^{\prime}$ S, $112^{\circ} 24^{\prime}$ E, HMAS Diamantina Station DM6/63/214, 11 October 1963, 70-72 fathoms, 2 fragmentary valves (part of S41332); WSW of Dongara, $2^{\circ} 29^{\prime} \mathrm{S}, 114^{\circ} 12^{\prime} \mathrm{E}$, HMAS Diamantina Station DM1/70/104, 8 December 1970, 60 fathoms, 2 right valves (WAM S34281); About $77 \mathrm{~km} \mathrm{SW}$ of Dongara, $29^{\circ} 21^{\prime} \mathrm{S}, 114^{\circ} 07^{\prime} \mathrm{E}$ to $29^{\circ} 21.5^{\prime} \mathrm{S}, 114^{\circ} 07.5^{\prime} \mathrm{E}$, RV Sprightly Station 20M, S.M. Slack-Smith, 18 February 1976, 146 metres, 6 fragments (WAM S34280); W of Dongara, $29^{\circ} 15^{\prime} \mathrm{S}, 114^{\circ} 01^{\prime} \mathrm{E}$, HMAS Diamantina Station DM1/72/055, B.R. Wilson, 20 March 1972, 139-146 metres, 1 fragmentary left valve and 1 right valve (WAM S34282); About 92 $\mathrm{km} \mathrm{W}$ of Dongara, $29^{\circ} 07^{\prime} \mathrm{S}, 113^{\circ} 57.4^{\prime} \mathrm{E}$ to $29^{\circ} 08^{\prime} \mathrm{S}$, $113^{\circ} 58 \mathrm{E}$, RV Sprightly Station 30M, S.M. Slack-Smith, 19 February 1976, 110 metres, 3 fragmentary valves (WAM S34279); Houtman Abrolhos Islands, E of Zeewyck Channel, $28^{\circ} 49^{\prime} \mathrm{S}, 113^{\circ} 47^{\prime} \mathrm{E}$, May 1960, 68-80 fathoms, 1 left valve (WAM S34283); SW of Bluff Point, $28^{\circ} 14^{\prime} \mathrm{S}, 113^{\circ} 28^{\prime} \mathrm{E}$, HMAS Diamantina Station DM1/64/040, 4 February 1964, 60 fathoms, 1 right valve and 1 left valve (WAM S41329); SW of Bluff Point, $28^{\circ} 14^{\prime} \mathrm{S}, 113^{\circ} 28^{\prime} \mathrm{E}$, HMAS Diamantina Station DM1/64/040, 4 February 1964, 60 fathoms, 1 left valve (WAM S41330); NW of Bluff Point, $27^{\circ} 40^{\prime} \mathrm{S}$, $113^{\circ} 03^{\prime} \mathrm{E}$, HMAS Diamantina Station DM6/63/131 CSIRO Station 131, 21 August 1963, 70 fathoms, 1 right valve and 2 fragmentary right valves (WAM S41331); off Kalbarri, $27.9351^{\circ} \mathrm{S}, 113.0810^{\circ}$ to $27.9441^{\circ} \mathrm{S}$, $113.0880^{\circ}$ E, S.M. Slack-Smith \& M.P. Salotti, Southern Surveyor Station SS 1005/098, 4 December 2005, 417-428 metres, 2 left valves (WAM S31372); Great Australian Bight, 130-155 metres, 1 pair conjoined valves (NMV F162007).

\section{Description}

Shell equivalve, prominently equilateral, large for genus, up to $96 \mathrm{~mm}$ in length, very tumid, ovate, somewhat truncated posteriorly; umbones broad, very prosogyral, not projecting above dorsal outline, situated at anterior one third to one fourth; posteriodorsal margin gently declined posteriorly, abruptly truncated by straight dorsal margin; dorsal margin sloping anteriorly; ventral margin uniformly convex to area of escutcheon, anteriodorsal margin short and concave; lunule prominent, sunken and bounded by incised line, sculptured with fine commarginal lamellae; escutcheon broad in left valve, well defined and relatively smooth; right valve escutcheon relatively narrow, more poorly defined and sculptured with prominent commarginal lamellae; radial sculpture of very fine ribs about as wide as interspaces, 24-38 ribs per $2 \mathrm{~cm}$ measured at about $5 \mathrm{~cm}$ from umbo; commarginal sculpture of dorsally recurved lamellae, corrugated by radial ribs.

Muscle scars subequal, anterior slightly smaller, D-shaped; posterior subrectangular. Pallial sinus broadly triangular. Row of prominent pallial

\section{Dimensions}

\begin{tabular}{lcccc} 
& & Length & Height & Inflation \\
\hline WAM S34274 & Holotype & 82 & 69 & 27 \\
WAM S41325 & Paratype & & 65 & 26 \\
WAM S41328 & Paratype & 59 & 50 & 42 (conjoined valves) \\
WAM S41326 & Paratype & 57.5 & 49 & 19 \\
WAM S41332 & Paratype & 80 & 67 & 27 \\
\hline
\end{tabular}




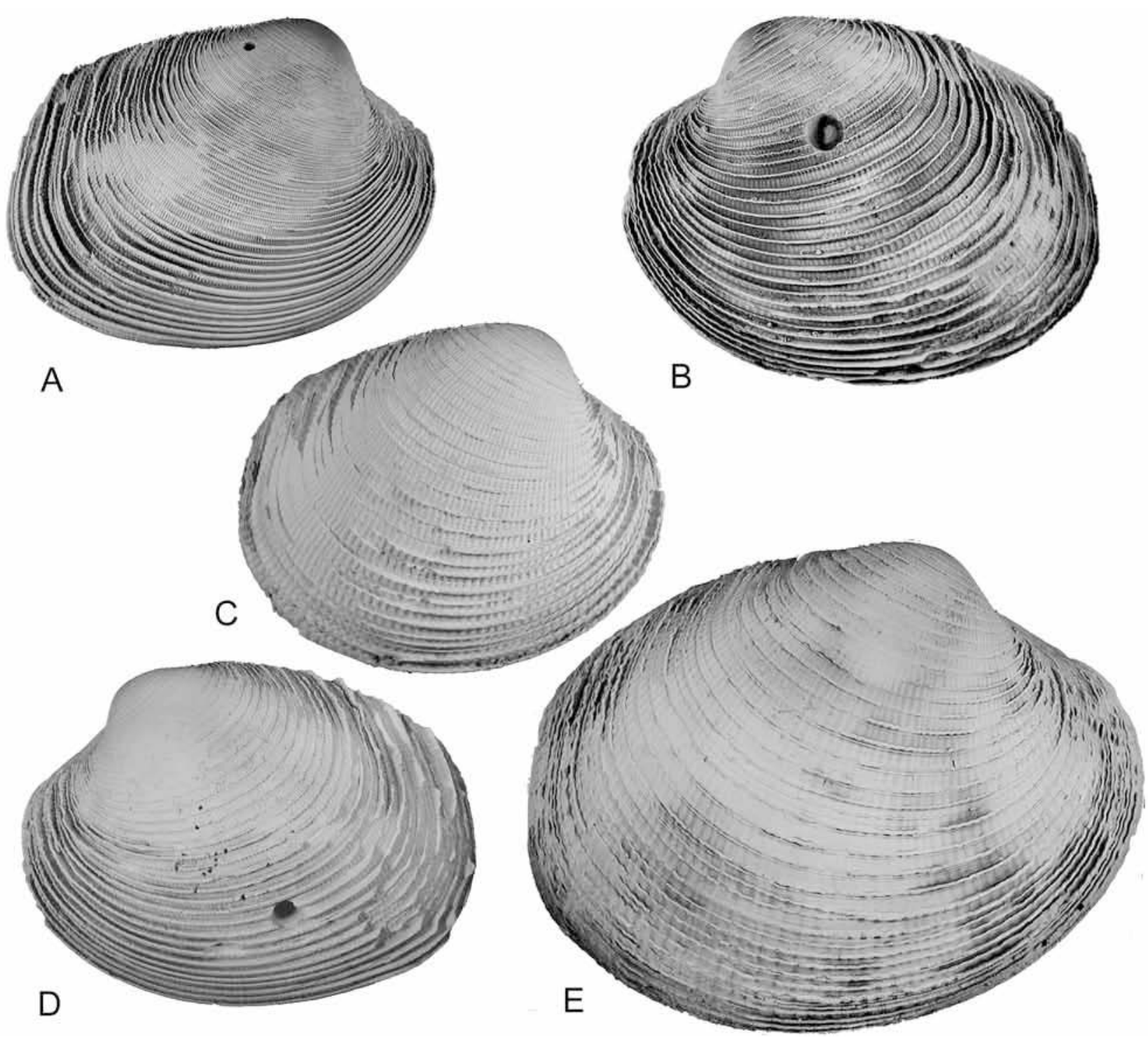

Figure 4 A, Proxichione subtilicostata Darragh, 1965, PL3082 Clifton Bank, Muddy Creek, Victoria (NMV P23822), holotype; B, D, Proxichione cognata (Pritchard, 1903), B, PL3167, $1.5 \mathrm{~km} \mathrm{~N}$ of Hampton Tower, Western Australia (NMV P315178); D, Grange Burn, Victoria (NMV P127613), holotype; C, E, Proxichione moondarae Darragh, 1965, C, PL3111, Moondarra Farm, Mitchell River, Victoria (NMV P23082), holotype, E, PL1264 Lot 22, Lackrana, Flinders Island, Tasmania (NMV P315180) (all x 1).

muscle attachment pits parallel to and inside pallial line and extending from anterior muscle scar to pallial sinus.

Left valve hinge with small pointed anterior lateral, narrow triangular anterior cardinal, broad triangular bifid central cardinal with deep, wide subcentral groove, posterior cardinal thin, elongate and subhorizontal. Right valve hinge with bladelike anterior cardinal, narrow median cardinal with shallow median groove, posterior cardinal narrow, elongate triangular with deep median groove. Internal margin of valves denticulate, denticulations finer and weaker on posterior margin.

\section{Remarks}

Proxichione elimatula has some resemblance to
P. subtilicostata Darragh, 1965, Miocene, Victoria (Figure 4A) particularly in the fineness of the ribs, but the valves are generally very much larger and much more tumid and the posterior end is abruptly truncated rather than gently rounded as in P. subtilicostata. The right valve central cardinal tooth is relatively thinner and the left anterior lateral tooth is much more prominent that in P. subtilicostata. It has coarser ribbing than in P. dimorphophylla (Tate, 1885), Miocene, South Australia, is much larger, much more tumid and more angular in outline with a broader posterior end. The right valve central cardinal tooth is also much thinner than that of $P$. dimorphophylla.

Specimens are about the same size as the type species of the genus, Proxichione materna Iredale, 
1929, central New South Wales coast (Figures 2 G-I, $\mathrm{K}-\mathrm{L})$, but the sculpture is much finer (24-38 versus 15-30 ribs per $2 \mathrm{~cm}$ ), the posterior end is more abruptly truncated and the left central cardinal tooth is much wider and more deeply split with a very wide groove.

Compared with P. chemnitzii (Hanley, 1845), from the western Indo-Pacific (Figures 2 D-F, J), the commarginal lamellae are recurved dorsally, the radial ribs are much finer and the outline less ovate than in P. chemnitzii.

\section{Proxichione moondarae Darragh, 1965} Figures $4 \mathrm{C}$, E

Proxichione moondarae Darragh, 1965: 170, plate 23, figures 18-21.

\section{Remarks}

This species was originally recorded from three localities in the Middle Miocene Gellibrand Formation (PL3087, PL3093, PL3102), from the type locality in the Tambo River Formation (PL3111, Late Miocene), from the Black Rock Sandstone (PL3130, Late Miocene) and from one locality in the Jemmys Point Formation (PL3118, Late Miocene). Additional material has been collected in Victoria from the Jemmys Point Formation (PL3123, Late Miocene), in South Australia from the Bookpurnong Formation (PL3298, PL3613, PL6667, Late Miocene) and from the Cameron Inlet Formation, Flinders Island, Tasmania (PL1229, PL1230, PL1234, PL1237, PL1238, PL1248, PL1264, Late Pliocene).

The Flinders Island specimens are slightly more tumid than are the topotypes and generally much larger in size and shell thickness. They are the largest Australian fossil venerids.

\section{Proxichione cognata (Prichard, 1903)} Figures 4B, D

Chione cognata Prichard, 1903: 101, plate 12, figure 5.

Proxichione cognata (Pritchard): Darragh, 1965: 171, plate 22, figures 14-5; plate 24, figures 24-5.

Proxichione sp. cf. P. cognata (Pritchard): Ludbrook, 1978: 70 , plate 8 , figures $1,3,5,7$.

\section{Remarks}

No specimens other than those figured by Darragh (1965) are known from the type locality at Forsyth's Bank, Grange Burn, Hamilton, despite much collecting, so it is not possible to obtain any idea of the variability in morphology of this taxon at the type locality. There are 12 well preserved specimens identified as this species from the Roe Calcarenite in Museum Victoria, which compare quite closely with the two topotypes in general shape and fineness of ribbing. The number of ribs is 21 to 24 per $2 \mathrm{~cm}$ compared with 24 for the two topotypes. There are some fragmentary specimens from the Dry Creek Sands, which compare reasonably well in shape, judging from the outlines of the younger portions of large fragmentary valves. These have from 23 to 31 ribs per $2 \mathrm{~cm}$, so perhaps have slightly finer ribbing when compared with the two topotypes and the specimens from the Roe Calcarenite. The age of the Dry Creek Sands is now believed to be late Middle Miocene and the age of the Roe Calcarenite Late Pliocene (Beu and Darragh 2001), which means that the stratigraphic range of Proxichione cognata is Middle Miocene to Late Pliocene, with the proviso that the record from the Dry Creek Sands is based on fragmentary specimens.

\section{ACKNOWLEDGEMENTS}

I am grateful to Barry Wilson (formerly of the Western Australian Museum), Shirley Slack-Smith and Corey Whisson (Western Australian Museum) and Ian Loch and Alison Miller (Australian Museum) for the loan of specimens. Adrian Bishop of Port Lincoln kindly donated a specimen of the new species.

\section{REFERENCES}

Beu, A.G. and Darragh, T.A., (2001). Revision of southern Australian Cenozoic fossil Pectinidae (Mollusca, Bivalvia). Proceedings of the Royal Society of Victoria 113: 1-205.

Darragh, T.A. (1965). Proxichione (Pelecypoda: Veneridae) from the Tertiary of South-Eastern Australia. Proceedings of the Royal Society of Victoria 79: 165-173.

Del Rio, C.J. (1994). Middle Miocene Bivalves of the Puerto Madryn Formation, Valdes Peninsule, Chubut Province, Argentina (Lucinidae-Pholadidae) Part II. Palaeontographica A 231: 93-132.

Gray, J.E. (1835). Catalogue of shells collected on the east coast of New Zealand by the Rev. W. Yate. In W. Yate, An account of New Zealand; and of the formation and progress of the Church Missionary Society's Mission in the Northern Island: 307-310. R.B. Seeley \& W. Burnside: London, U.K.

Hanley, S.C.T. (1845). Descriptions of new species of Cyrena, Venus and Amphidesma. Proceedings of the Zoological Society of London 1844: 159-162.

Ihering, H. von (1897). Os Molluscos dos terrenos terciarios da Patagonia. Revista do Museu Paulista 2: 217-382, pl. 3-9.

Ihering, H. von (1907). Les Mollusques fossiles du Tertiaire et du Crétacé supérieur de l'Argentine. Anales del Museo Nacional de Buenos Aires, ser. 3, 7: 1-611.

Iredale, T. (1929). Strange molluscs in Sydney Harbour. Australian Zoologist 5: 337-352.

Iredale, T. (1930). More notes on the marine mollusca of New South Wales. Records of the Australian Museum 17: 384-407.

Jansen, P. (2000). Seashells of South-Eastern Australia. Capricornia Publications, Lindfield, Australia. 
Jukes-Browne, A.J. (1914). A synopsis of the family Veneridae. Proceedings of the Malacological Society of London 11: 58-94.

Lamprell, K. and Whitehead, T. (1992). Bivalves of Australia, vol 1. Crawford House Press: Bathurst, Australia

Linné, C. (1758). Systema naturae per regna tria naturae, secundum classes, ordines, genera, species cum characteribus, differentiis, synonymis, locis. L. Salvii: Holmiae, Sweden.

Ludbrook, N.H. (1978). Quaternary Molluscs of the western part of the Eucla Basin. Geological Survey of Western Australia Bulletin 125: 1-286.
Maxwell, P.A. (1978). Taxonomic and nomenclatural notes on some New Zealand Cenozoic Mollusca, with descriptions of new taxa. New Zealand Journal of Zoology 5: 15-46.

Rafinesque, C.S. (1815). Analyse de la Nature, ou Tableau de l'Univers et des Corps Organises. Author: Palermo, Italy.

Schumacher, C.F. (1817). Essai d'un nouveau système des habitations des vers testacés. F. Schultz: Copenhagen, Denmark.

Manuscript received 16 October 2008; accepted 13 January 2009. 